\title{
中空軸を持つ一軸浮上制御磁気軸受の提案と非接触回転駆動への応用
}

\author{
廣瀬 健太郎 $^{\mathrm{a}} \quad$ 小森 望充 ${ }^{\mathrm{a},{ }^{*}}$ 浅海 賢一 ${ }^{\mathrm{a}}$ 坂井 伸朗 ${ }^{\mathrm{a}}$
}

\section{Proposal of One Axis Controlled Magnetic Bearing with a Hollow Shaft and its Application to No-Contact Rotation Drive}

\author{
Kentaro Hirose $^{\mathrm{a}}$, Mochimitsu Komori ${ }^{\mathrm{a},}{ }^{*}$, Kennichi Asami $^{\mathrm{a}}$, Nobuo Sakai $^{\mathrm{a}}$
}

(Received January 28, 2015; revised March 2, 2015; accepted March 4, 2015)

\begin{abstract}
We propose a novel configuration of magnetic bearing for left ventricular assist device (LVAD) to realize simple and small LVAD. The magnetic bearing consists of a cylindrical stator with an inner ring and an outer ring and a rotor. The magnetic bearing and a displacement sensor have a hollow as a flow channel. In order to simplify the system, the magnetic bearing has the one axis controlled rotor in the axial direction. The displacement sensor coil in the axial direction is put in the center of stator. In this study, the displacement sensor is applied to the magnetic bearing and investigated. Magnetic field analysis was performed in order to evaluate magnetic flux of permanent magnet and force in the axial direction. Some experiments for levitation and rotation were performed.
\end{abstract}

キーワード：磁気軸受, 一軸制御, 永久磁石, 中空軸

Keywords : magnetic bearing, one axis control, permanent magnet, a hollow shaft.

\section{1. 緒言}

\section{1 背景}

磁気軸受とは回転軸を磁気的な力により非接触で支持す る軸受のことで, 機械的な接触がある転がり軸受とは異なり， 軸と軸受間に摩擦や摩耗がないため, 高寿命かつメンテナン スフリーである。また，摩擦，摩耗がないため，潤滑を必要 とせず，摩擦，摩耗で発生する塵埃や潤滑油蒸発が問題とな るクリーンルームや真空中, 生体内での使用が可能である。 上記の利点から, 磁気軸受は様々な分野への応用の研究, 開 発が行われており，その一つに人工心臓への適用が挙げられ

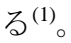

人工心臓は完全置換型と補助型が研究, 開発されてい る。また, 人工心臓の駆動方法は拍動式と連続流式に大 別され，連続流式には遠心ポンプと軸流ポンプ等が挙げ られる。小型, 高耐久でメンテナンスをあまり必要とし ない等の機能が人工心臓に求められ，更に省電力化のた め能動型と受動型を組み合わせた磁気軸受を用いた軸流 式が研究されている ${ }^{(1,2)}$ 。

\footnotetext{
* Corresponding author. E-mail: komori_mk@yahoo.co.jp

a 九州工業大学

干804-8550 福岡県北九州市戸烟区仙水町 1-1

Kyushu Institute of Technology

1-1, Sensui, Tobata, Kitakyushu, Fukuoka, Japan 804-8550
}

人工心臓に採用される磁気軸受には小型で安定して 高速回転できる等の性能が求められる。そこで, 小型で 高効率な人工心臓を実現するために, 先行研究では, 2 〜3 自由度を能動型と受動型を組み合わせた構造を採用 している(2-7)。しかしながら, 装置全体を小型化すること に重きを置き，ステータを縮小すると浮上コイルの巻数 が多くできず，コイルの線径を小さくすると必要な電流 が流せないため, 単位面積当たりで発生する力が小さく なってしまう等の問題がある。また，2〜3 自由度を一組 のステータで受動支持や能動制御する場合，ロータの扁 平化や永久磁石の増設, 各方向の制御のためのコイルを 必要とするため, 装置の大型化が避けられないと共に, 装置の構造, システムを複雑にしてしまう問題がある。

\section{2 目的}

本研究では左心室補助型人工心臓への適用を目指し た単純な装置構造の磁気軸受を提案する。提案する磁気 軸受は軸流式ポンプを想定しているため，軸方向からロ 一夕を磁気支持する構造とする ${ }^{(8-10)}$ 。そこで本研究では, ロータを磁気支持するステータは，ロータの軸両端を挟 み込み，軸方向の一軸のみを浮上制御する。また，ステ 一タは装置の構造と制御系の簡単化のため, 内環と外環 を持つシリンダー状である。軸流式ポンプでは一般的に， 


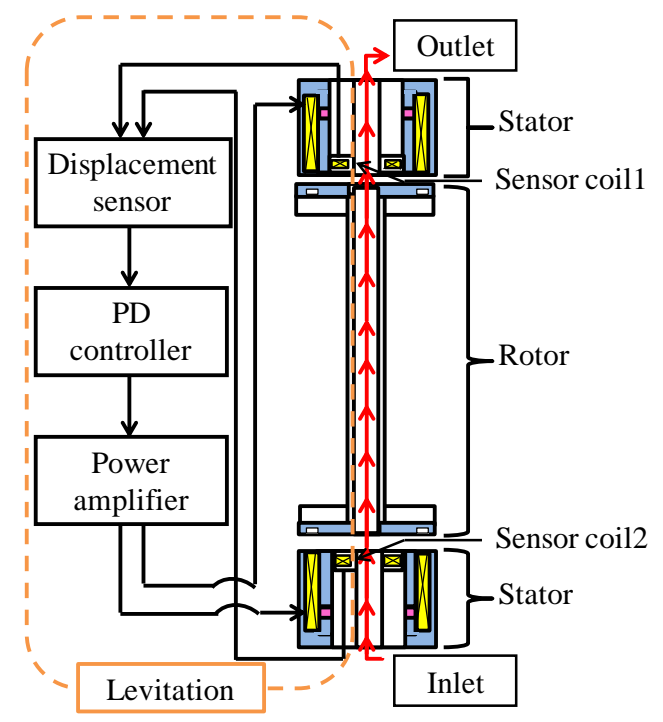

Fig. 1. Magnetic bearing configuration.
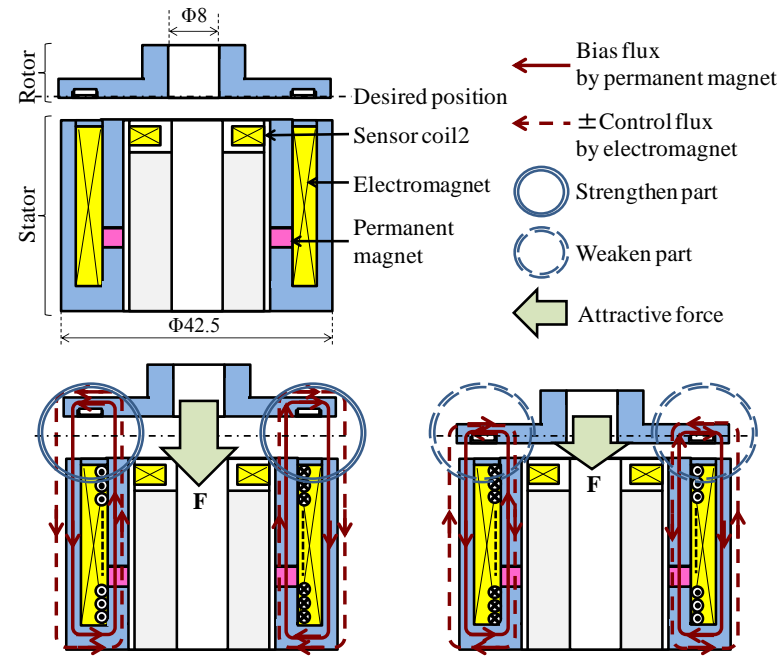

Fig. 2. Method of levitation control.

ロータの側面にインペラがあるため側面に流路を持つが， 本研究ではロータの中心部に流路を持つ中空軸構造を採 用する ${ }^{(11,12)}$ 。ロータの中心部に中空軸を持たせることに よって，ロータとケーシングとの間にワイドギャップを 必要とせず, 半径方向の大きさを小さくすることを図る。 また，この構造を実現するため，ロータの中央部の流路 と同径の穴を持つセンサコイル及びステータを用いる。 本研究では提案した磁気軸受を実際に作製し, 回転時の 動特性の評価, 検討を行う。

\section{2. 基本的な構成}

\section{1 磁気軸受の基本構成}

Fig. 1 は, 提案するロータ中心部に流路を想定した中 空軸を持つ一軸浮上制御軸受の簡略モデルである。ロー タ, ステータは共に電磁軟鉄で出来ている。また, ロー

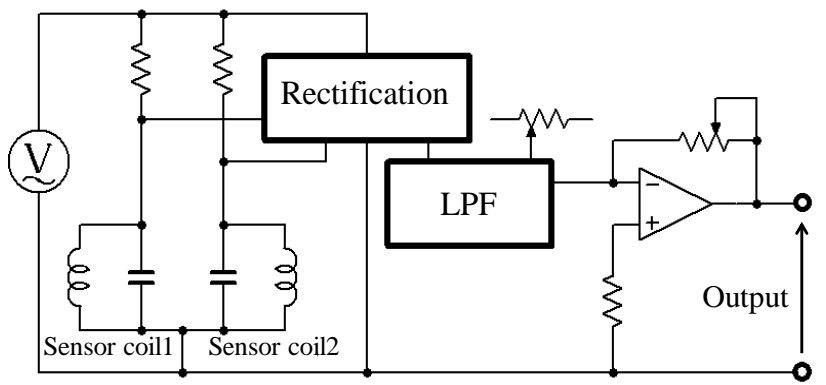

Fig. 3. Detecting circuit of displacement sensor.

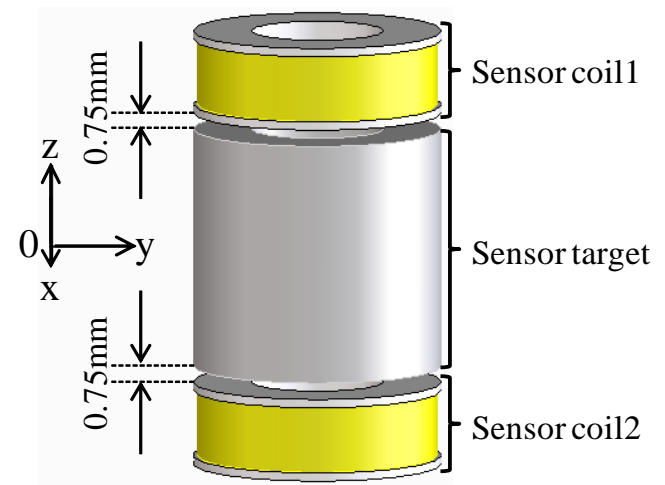

Fig. 4. Experimental setup for displacement sensor.

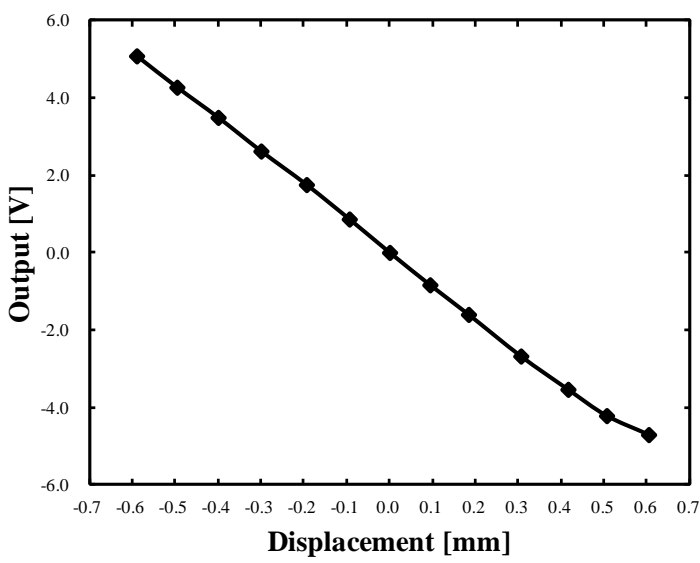

Fig. 5. Output of displacement sensor vs. displacement between coil and sensor target.

タとステータは共に外直径が $42.5 \mathrm{~mm}$ である。ロータは ロータの軸両端に位置するシリンダー状のステータによ ってプッシュプル的に浮上制御される。磁気軸受の全体 の制御システムと下側のロータに働く力を Fig. 2 に示す。 Fig. 2 は Fig. 1 の下側のステータとそれと対向するロー タの鉄部分を拡大したものである。本研究では浮上制御 に必要な電力の省電力化と浮上用コイルのスペースの縮 小化のため, リング状の永久磁石をステータの内環部に 


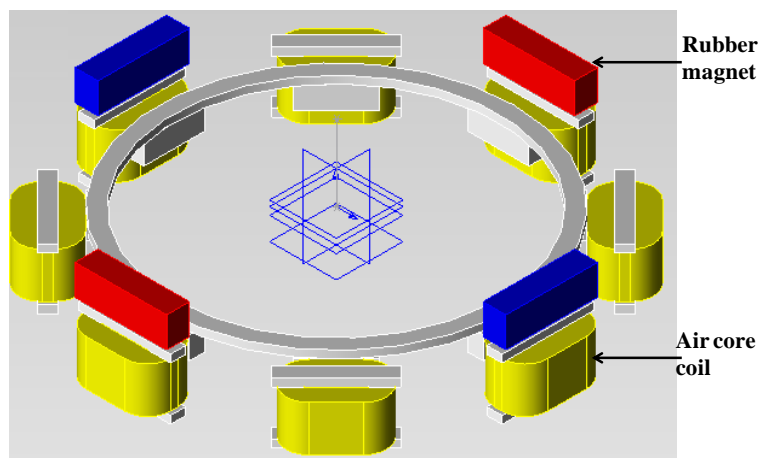

(a) Stator with 8-pole coils and rotor with rubber magnets.

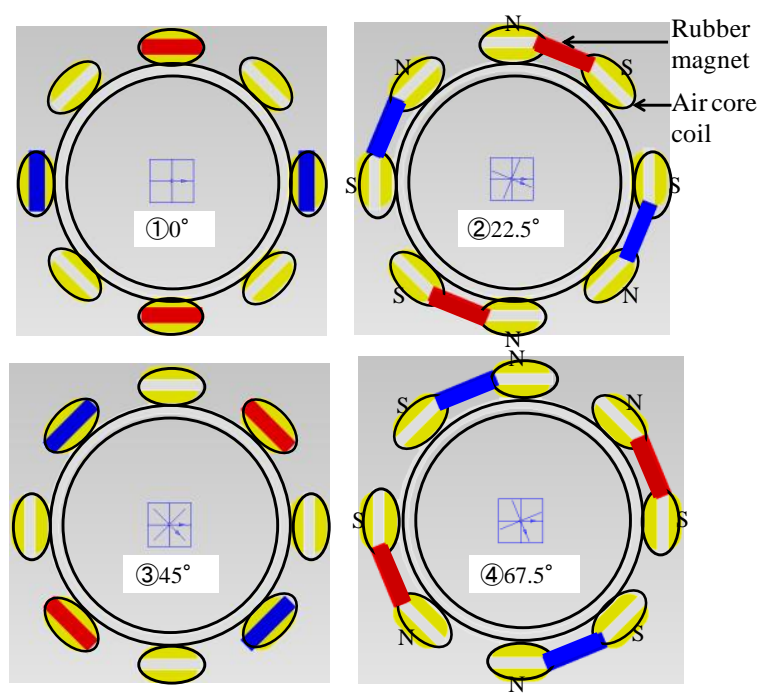

(b) Excitation pattern.

Fig. 6. Configuration of motor.

設け，バイアス磁束を得ることを図った。永久磁石の外 直径 $30 \mathrm{~mm}$, 内直径 $23 \mathrm{~mm}$, 磁化方向厚さ $3.0 \mathrm{~mm}$, 表面 磁束密度 $322 \mathrm{mT}$ である。ロータ, ステータ間のエアギャ ップは上下共に $0.75 \mathrm{~mm}$ である。各浮上用コイルは線直 径 $0.5 \mathrm{~mm}, 266$ 巻であり，ステータの内環と外環の間に 納められている。上下の浮上用コイルには，制御コント ローラからの信号を正負反転して（上側が正のままなら， 下側は負に変換）入力する。電磁石が発生させる磁束の 向きを切り替えることで永久磁石のバイアス磁束と合わ せてロータに働く吸引力を発生させ，上側も同様に制御 を行うことによって，ロータを目標位置に安定浮上させ る。

\section{2 変位センサの原理と特性}

提案する一軸浮上制御磁気軸受システムを構成する にあたり，流路となる中空軸を持つ変位センサの検出回 路を Fig. 3 に示す。変位センサは, センサターゲットと 各センサコイル間のギャップによる相互インダクタンス から各出力電压を得て, センサコイル 1 とセンサコイル 2 の電圧差を得ることによって，ギャップを求める。ま た，使用温度範囲が広いことと，回路がブリッジ構成の

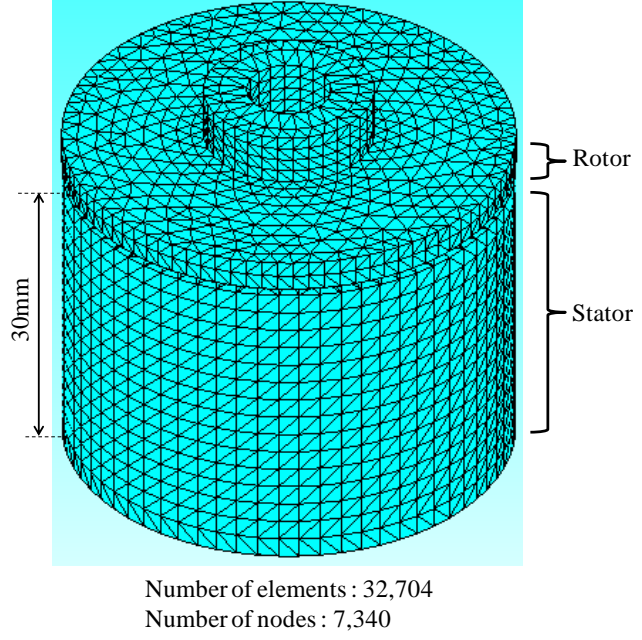

Fig. 7. Analysis model.

ため安定度が高いという利点があり, 消費電流は $30 \mathrm{~mA}$ 以下と非常に小さい。Fig. 4 に変位センサの本磁気軸受 への有用性を確認するための実験方法の概略図を示す。 変位センサの二つのコイル（Sensor coil1, Sensor coil2) と変位センサと同直径 $8 \mathrm{~mm}$ の中空軸を持つセンサター ゲットとのエアギャップを上下それぞれ $0.75 \mathrm{~mm}$ に配置 する。 $\mathrm{x}, \mathrm{y}$ 軸は半径方向を, $\mathrm{z}$ 軸は軸方向を示している。

Fig. 5 は 0 位置から z 軸方向上下にセンサターゲットを 変位させた際の出力電圧を示しており，使用範囲におい て出力に線形性が見られるため, 本研究での使用におい て十分な性能が得られることがわかった。したがって, この変位センサからの信号を制御コントローラに入力し, $\mathrm{PD}$ 制御を行うことでロータの安定浮上を図る。

\section{3 モータの構成}

一軸浮上制御磁気軸受において基礎的な浮上回転実 験を行うため, ロータ側の片側 4 極のゴム磁石と, ステ 一タ側の片側 8 スロットの空芯コイルからモータを構成 した。基礎的な浮上確認を行うため, ロータには加工が 比較的に容易な点から, 磁化方向厚さ $3.0 \mathrm{~mm}$ のゴム磁石 を用いた。空芯コイルは線直径 $0.3 \mathrm{~mm}$ で各 128 巻である。 ゴム磁石と空芯コイルの配置を Fig. 6 (a)に，コイルへの 励磁パターンの一例を Fig. 6 (b)に示す。ゴム磁石とコイ ルは向き合うように配置されている。ゴム磁石とコイル が向き合う際はコイルに電流は流れず，ゴム磁石がコイ ル間に位置した時を Fig. 6 (b)に示すようにコイルの極を 切り替えることで $22.5^{\circ}$ ずつ回転させる。

\section{3. 磁気軸受の有限要素解析と浮上性能評価}

\section{1 有限要素解析}

本研究で提案する中空軸を持つ一軸浮上制御磁気軸 受の吸引力特性の解析を行った。下側のステータと対面 するロータ部分の解析モデルを Fig. 7 に示す。要素数は 32,704, 節点数は 7,340 である。Fig. 7 の解析モデルを基 


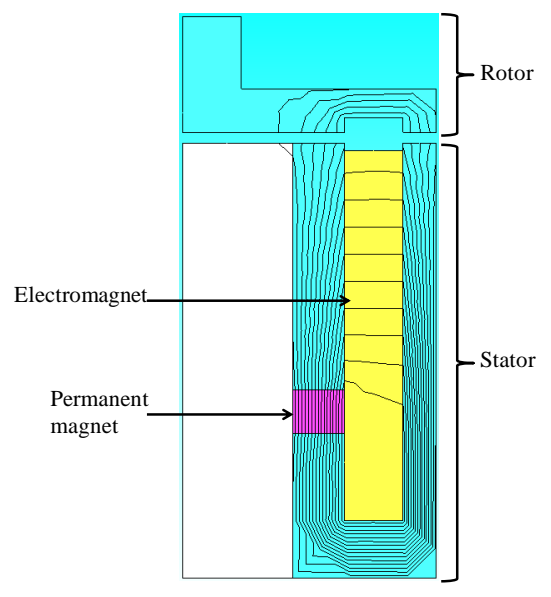

(a) Bias flux line.

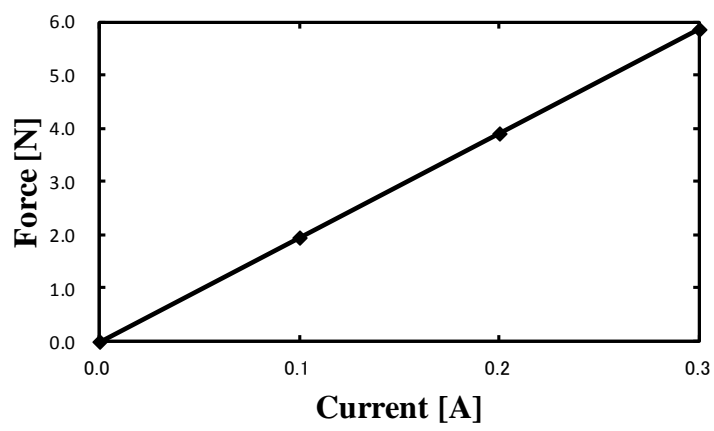

(b) Attractive force in the axial direction vs. current.

Fig. 8. Magnetic flux lines and attractive force (Result of analysis).

に，浮上用コイルに流れる電流が $0 \mathrm{~A}$ の際のロータ及び ステータを通る磁束線と浮上用コイルに流れる電流を変 化させた時のロータに働く吸引力を Fig. 8 に示す。Fig. 8 (a)より，磁束線が内環から外環にかけて所望の通りに閉 じていることがわかる。Fig. 8 (b)より，浮上用コイルに 流れる電流を变化させた時, 発生する吸引力に線形性が 見られる。

\section{2 磁気軸受の吸引力評価}

提案した磁気軸受の吸引力を確認するため, 実際に作 製したロータ及びステータを用いて，解析同様，浮上用 コイルに流れる電流を変化させた時, 発生する吸引力に ついて測定を行った。その結果を Fig. 9 に示す。Fig. 9 の吸引力は解析結果 Fig. 8 (b) と比べて僅かに小さいが, いずれも発生する吸引力に線形性が見られた。

\section{4. 中空軸を持つロータの浮上及び回転実験}

\section{1 浮上性能評価}

提案した磁気軸受の浮上性能を確認するため, 実際に 作製した磁気軸受を用いて，浮上時のゲインの測定，イ ンパルス応答実験，ステップ応答実験を行った。軸方向

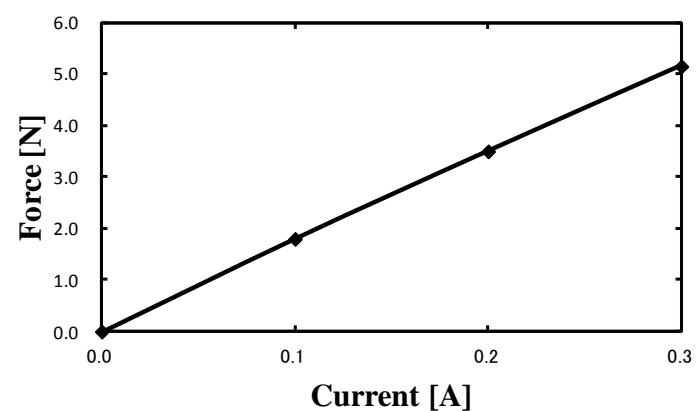

Fig. 9. Attractive force in the axial direction vs. current (Result of experiment).

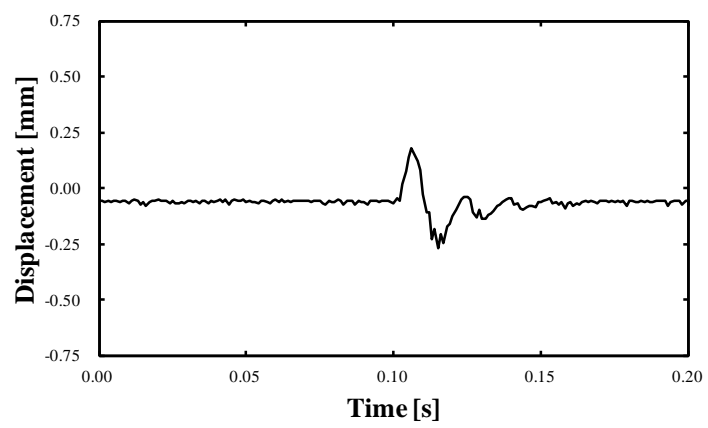

Fig. 10. Impulse response.

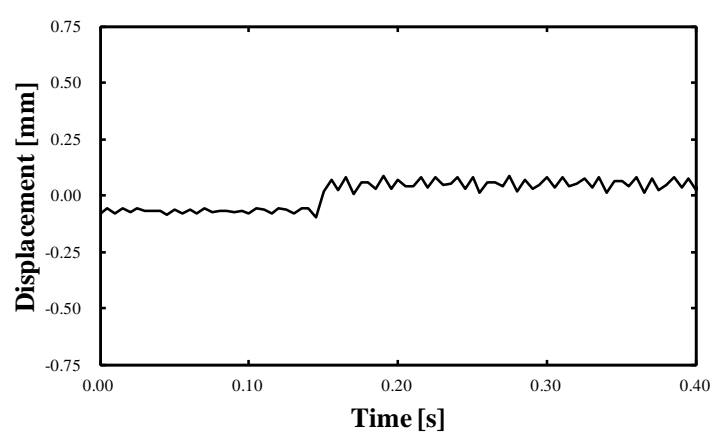

Fig. 11. Step response.

制御のための制御ゲインは試行錯誤的に決定し，比例ゲ インは $3.14 \mathrm{~A} / \mathrm{mm}$, 微分ゲインは $0.13 \mathrm{As} / \mathrm{mm}$ とした。

ロータを軸方向の一軸のみで浮上制御した状態で，浮 上用コイルに外乱として擬似的なインパルスカを電気的 に印加した場合のインパルス応答を測定した。実験では ロータ，ステータ間のエアギャップの $1 / 3$ 程度の振幅に なる様にインパルスカを与えた。その結果を Fig. 10 に示 す。実験結果から，インパルス応答の振幅は約 $0.25 \mathrm{~mm}$, 静定時間は約 $0.05 \mathrm{~s}$ となっていることがわかる。エアギ ヤップの $1 / 3$ 程度の振幅を持つインパルスカを与えたに も拘らず，良好な即応性を確認することができた。

同様に，ロータを軸方向の一軸のみで浮上制御した状 態で，浮上用コイルに振幅が $0.10 \mathrm{~mm}$ となる様なステッ 


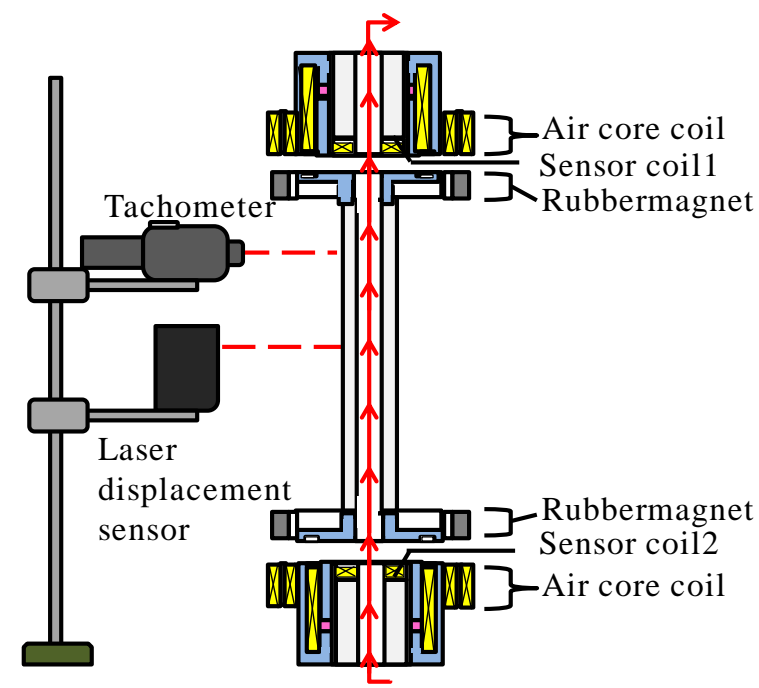

Fig. 12. Experimental setup.

プ状の外乱を電気的に印加した。そのステップ応答を Fig. 11 に示す。実験結果から, ステップ応答の振幅は約 $0.10 \mathrm{~mm}$, 静定時間は約 $0.01 \mathrm{~s}$ となっていることがわかる。 定常位置から約 $0.10 \mathrm{~mm}$ 変位するようなステップ状の外 乱を印加した時，良好な即応性と变位後も良好な浮上制 御を実現することができた。

\section{2 回転実験}

Fig. 6 (a)の 8 スロットモータを用いて, Fig. 12 に示す 実験装置を構成した。浮上回転実験の結果をFig. 13 に示 す。軸方向変位はステータ中央に納められた変位センサ を, 半径方向変位はレーザ変位計を, 回転数は光学式の 非接触型タコメータを使用して測定した。回転駆動用の 空芯コイルにはそれぞれ 0.6A の励磁電流を流した。

Fig. 13 (a)は浮上回転時の時間に対する回転速度を示 しており, 次第に回転速度が増加し, 最大 $350 \mathrm{rpm}$ で回 転していることがわかる。Fig. 13 (b)は時間に対する軸方 向変位を示しており, ロータの回転速度が次第に増加し ても，軸方向の変位が $0.2 \mathrm{~mm}$ 以下と小さいことがわかる。 また, 浮上用コイルに流れる電流は約 $0.2 \mathrm{~A}$ と小さかった。 しかし,一組のステータを用いてプッシュプル方式で PD 制御を行ったが，両方のステータの特性が正確に等しく ないため, ロータが目標点 0 から少しずれた位置で釣り 合っていることがわかる ${ }^{(13)}$ 。Fig. 13 (c) は時間に対する半 径方向変位を示しており, Fig. 13 (b)の軸方向変位と比心゙ て, 半径方向の変位が大きいことがわかる。これは半径 方向の変位に対して能動的な制御や受動支持装置を設け ておらず，各浮上用ステータの軸方向制御によって得ら れる半径方向吸引力のみによって半径方向の変位を受動 支持しているためである。また，70s 以降の振幅が増大 しているのは, 磁気軸受による受動支持が十分でないた めだと考えられる。

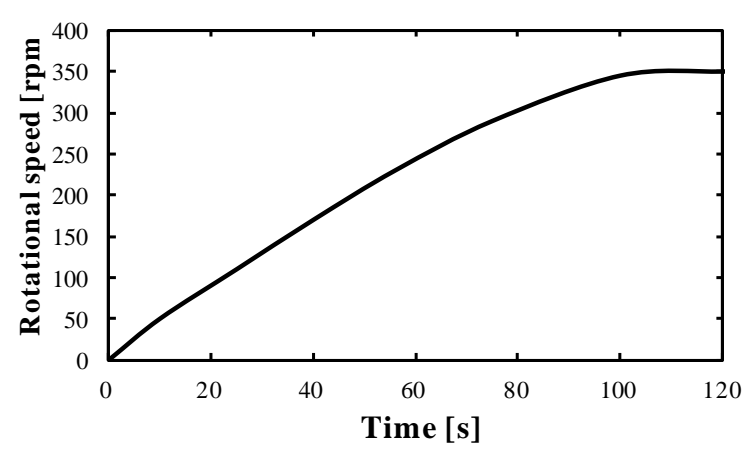

(a) Rotational speed

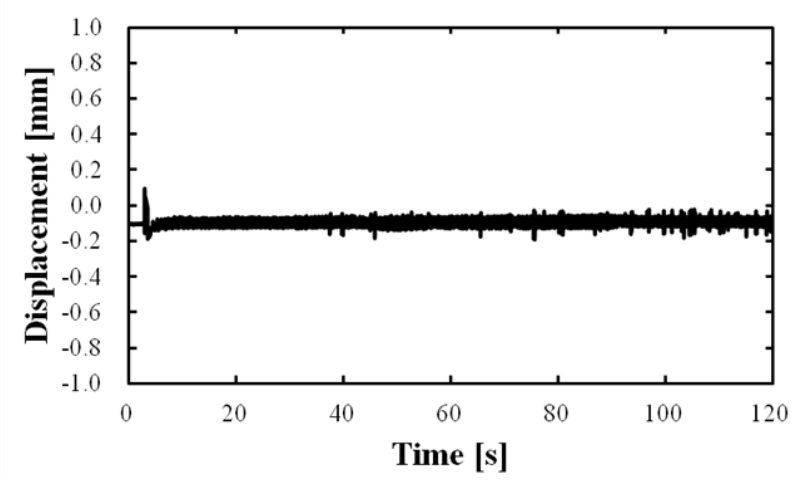

(b) Displacement in the axial direction.

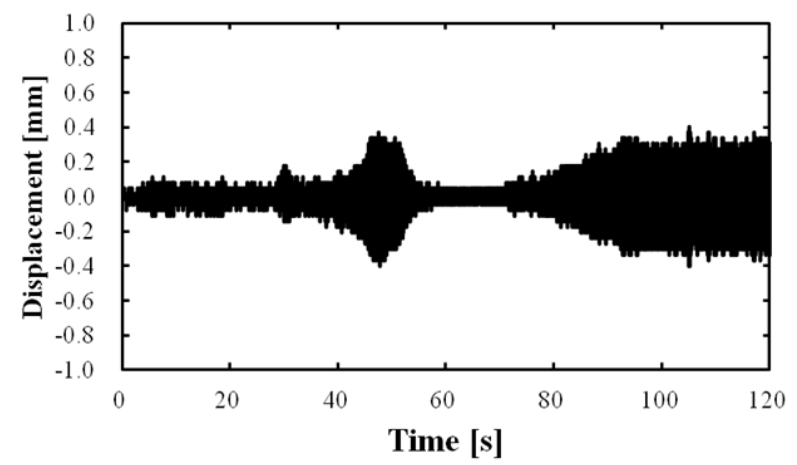

(c) Displacement in the radial direction.

Fig. 13. Result of stable levitation and rotation.

\section{5. 結言}

左心室補助型人工心臟一の適用を想定し, ロータの軸 両端を永久磁石と電磁石から成るシリンダー状のステー 夕で挟み込み, 一軸のみを浮上制御する磁気軸受の構造 を提案した。また，提案した磁気軸受は流路を想定した 中空軸を持っている。提案した磁気軸受に用いる同直径 の中空軸を持つ変位センサに関して出力特性の測定を行 い，その有用性を確認した。提案した磁気軸受の磁場解 析モデルと実際に作製した磁気軸受とで発生する吸引力 の比較を行った。その結果, 僅かに違いがあるものの, 
所望の結果を得られた。また，実際に作製した磁気軸受 と一つの変位センサを用いた浮上システムにおいて外乱 への応答試験を行い, 良好な即応性と浮上制御特性を確 認した。片側 4 極のゴム磁石と片側 8 スロットの空芯コ イルを用いて回転実験を行い，最高 $350 \mathrm{rpm}$ で回転する ことを確認した。

今後は半径方向変位と傾きに対する制御方法の検討 とロータの中空軸にインペラを取り付けて，揚程実験等 を行っていきたい。

\section{文献}

(1) 電気学会磁気浮上応用技術調查専門委員会：「磁気浮上と磁気軸 受」,コロナ社, 1998

（2）栗田伸幸，石川赴夫，手塚孝幸，高田敬夢：「5 自由度能動制御型 磁気浮上モー夕に関する研究」, 日本機械学会論文集 C 編, Vol. 79, No. 801, pp. 236-249, 2013.

(3) 山城直人, 岡田養二:「コンシークエント型アキシャルセルフベア リングモータの開発と応用」, 日本 AEM 学会誌, Vol. 14, No. 1, pp. 2-7, 2006.

（4）湯本淳史, 進士忠彦, 張暁友, 下河辺明：「小型遠心血液ポンプ用 1 自由度制御型磁気浮上モータ」, 第 20 回「電磁力関連のダイナ ミクス」シンポジウム論文集，pp. 129-132， 2008.

（5）黑須宽秋, 増澤徹, 加藤綾子, 小沼弘幸, 柿原功一：「4 軸制御型 磁気軸受を用いた磁気浮上クリーンポンプの研究開発」, 日本 AEM 学会誌, Vol. 17, No. 2, pp. 309-316, 2009.

(6) 山根隆志：「人工心臟の技術開発」, ながれ, Vol. 20, No. 6, pp 435-438, 2001

(7) Sung Hoon Kim, Shuichiro Hashi, and Kazushi Ishiyama : "Actuation of Novel Blood Pump by Direct Application of Rotating Magnetic Field", IEEE transactions on Magnetics, Vol. 48, No. 5, pp. 1869-1874, 2012

(8) Yohji Okada, Toru Masuzawa, Ken-Ichi Matsuda, Kunihiro Ohmori, Takashi Yamane, Yoshiaki Konishi, Shinya Fukahori, Satoshi Ueno, and Seung-Jong Kim : "Axial Type Self-Bearing Motor for Axial Flow Blood Pump", Artificial Organs, Vol. 27, No. 10, pp. 887-891, 2003.

(9) S. Neethu, K. S. Shinoy, and A. S. Shajilal : "Novel Design, Optimization and Realization of Axial Flux Motor for Implantable Blood Pump", International Conference on Power Electronic Drives and Energy Systems for Industrial Growth, pp.1-6, 2010.

（10）湯本淳史，進士忠彦：「軸方向制御型磁気軸受モータを搭載した小 型血液ポンプ」, 日本機械学会論文集 C 編, Vol. 78, No. 792, pp. 3064-3072, 2012.

(11) Sheng-Ming Yang and Ming-Shi Huang : "Design and Implementation of a Magnetically Levitated Single-Axis Controlled Axial Blood Pump", IEEE Transactions on Industrial Electronics, Vol. 56, No. 6, pp. 2213-2219, 2009

(12) 住倉博仁, 福長一義, 舟久保昭夫, 福井康裕 :「軸流血液ポンプ用
エンクローズインペラの提案と CFD を用いた工学的検証」, ライ フサポート, Vol. 20, No. 1, pp. 9-16, 2008.

(13) 田鍾業，八ネス・ブロイレル，樋口俊郎：「磁気浮上システムのオ 一トチューニングレギュレータ」, 東京大学生産技術研究所生産研 究, Vol. 46, No. 12, pp. 690-693, 1994.

(14) 大石哲男, 志村誠治, 岡田養二:「同期型および誘導型磁気浮上回 転モー夕の研究」, 電気学会論文誌, Vol. 115, No. 3, pp. 342-347, 1995.

（15）上野哲，金箱秀樹，山根隆志，岡田養二：「永久磁石反発を用いた 1 軸制御アキシャル磁気浮上モータの浮上回転実験」, 日本 AEM 学会誌, Vol. 8, No. 2, pp. 239-245, 2000

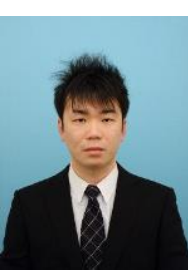

廣瀬 健太郎

2010 年 3 月九州工業大学工学部電気工学科卒 業。同年 4 月九州工業大学工学大学院府先端機能 システム工学専攻入学, 現在に至る。磁気軸受の 研究に従事。

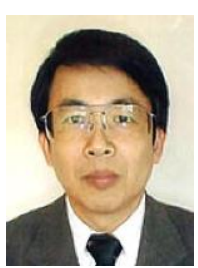

小森 望充

1984 年 3 月大阪大学基礎工学研究科制御工学分 野修了。2008 年 4 月九州工業大学大学院工学研究 院先端機能システム工学研究系教授, 現在に至る。 磁気浮上及び超電導応用メカトロニクスの研究に 従事。

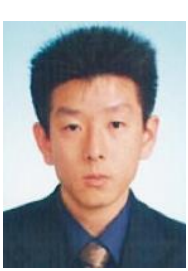

浅海 賢一

1992 年 3 月九州工業大学情報工学研究科情報科 学卒業。2008 年 4 月九州工業大学府大学院工学研 究院基礎科学研究系准教授, 現在に至る。ビジュ アルトラッキングシステムにおけるリアルタイム モーター制御の研究に従事。

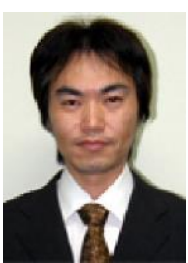

坂井 伸朗

2002 年 3 月九州大学工学研究科知能機械システ 厶専攻修了。2011 年 1 月九州工業大学大学院工学 研究院先端機能システム工学研究系准教授, 現在 に至る。生体機能設計学 (バイオニックデザイン) の研究に従事。 